SHS Web of Conferences 2, 00002 (2012)

DOI: $10.1051 /$ shsconf $/ 20120200002$

(C) Owned by the authors, published by EDP Sciences, 2012

\title{
Economic evaluation as a decision-making tool in health care
}

\author{
D. Araja
}

\author{
Rīga Stradiņš University, Latvia
}

\begin{abstract}
For the assessment of the health care system efficiency result-oriented indicators should be exploited much more actively as without specific indicators oriented to the evaluation of the patient's health outcomes it is impossible to acquire reasonable evidence for the effectiveness of the functioning of the health care system that has the decisive role for further decisions in the age of the evidence-based medicine. The main groups of the treatment results' indicators are clinical, economic and patient-reported outcomes (PROs), and all these groups of outcomes should be considered to make the most objective economic evaluation. This research has been determined to investigate applying of PROs as a relatively new tool in evaluation of the health care in Latvia. The results of the scientific publications review show that the positive trend in using of the PROs in Latvia is observed, but the involvement of patients in treatment' process assessment is not enough active yet. The relevant problems and possible suggestions for improvement of this process are discussed in the article.
\end{abstract}

Key words: patient-reported outcomes, economic evaluation, health care, Latvia

The economic evaluation of the treatment process is gaining popularity and recognition all over the world due to the introduction of increasingly new technologies in medicine and pharmacy that facilitate achieving inexperienced summits in treating patients; however often simultaneously make the treatment process more expensive. An economic evaluation in health care is defined as "the comparative analysis of alternative courses of action in terms of both their costs and consequences" (Drummond et al., 2000). The Figure 1 demonstrates the structure of an economic evaluation of the treatment process.

The costs are defined as (Kobelt, 2002):

- Direct costs, i.e. costs related to the use of resources due to either the disease or its treatment. They include costs to the health care system, but also to social services and to patients themselves or to their relatives.

- Indirect or productivity costs, i.e. costs related to loss of production, due to either the disease or its treatment, which occur to society.

- Intangible costs, i.e. costs related to suffering and the loss of quality of life due the disease or its treatment, which occurs to the patient. These costs are particularly difficult to measure and value and, as a result, are often left out of any analysis.

In determining economic efficiency a significant role belongs to a precise, clear and motivated identification of costs and benefits because the fundamental postulate of cost-effectiveness is based on the assumption that benefits must exceed the costs arising in the process of achieving the benefits. The health care system, however, encounters several problems in establishing cost-effectiveness both regarding the health care system as a whole as well as choosing a specific kind of treatment. One of the main problems is the measurement of the outcomes, because the costs demonstrate the dominated prevalence in monetary value. By reason of the insufficient direct quantitative measures of benefits the qualitative measures are introduced in economic evaluation of the treatment process. The most widely used outcomes' measures are the physiological measures and clinical events, survival,

This is an Open Access article distributed under the terms of the Creative Commons Attribution License 2.0, which permits unrestricted use, distribution, and reproduction in any medium, provided the original work is properly cited. 


\section{SHS Web of Conferences}

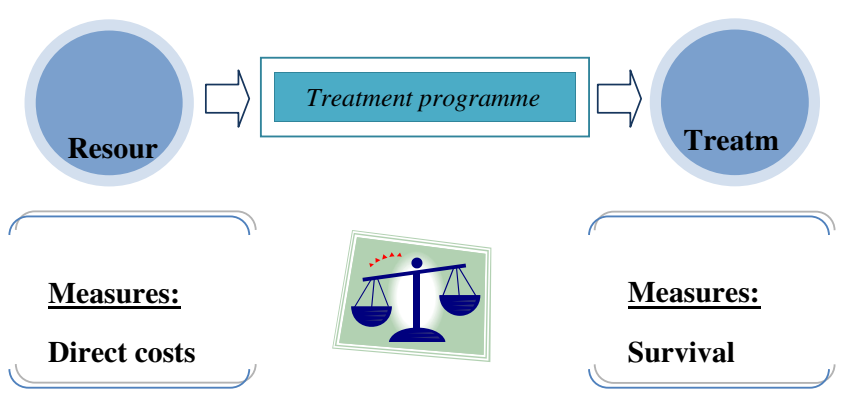

Figure 1. Structure of economic evaluation.

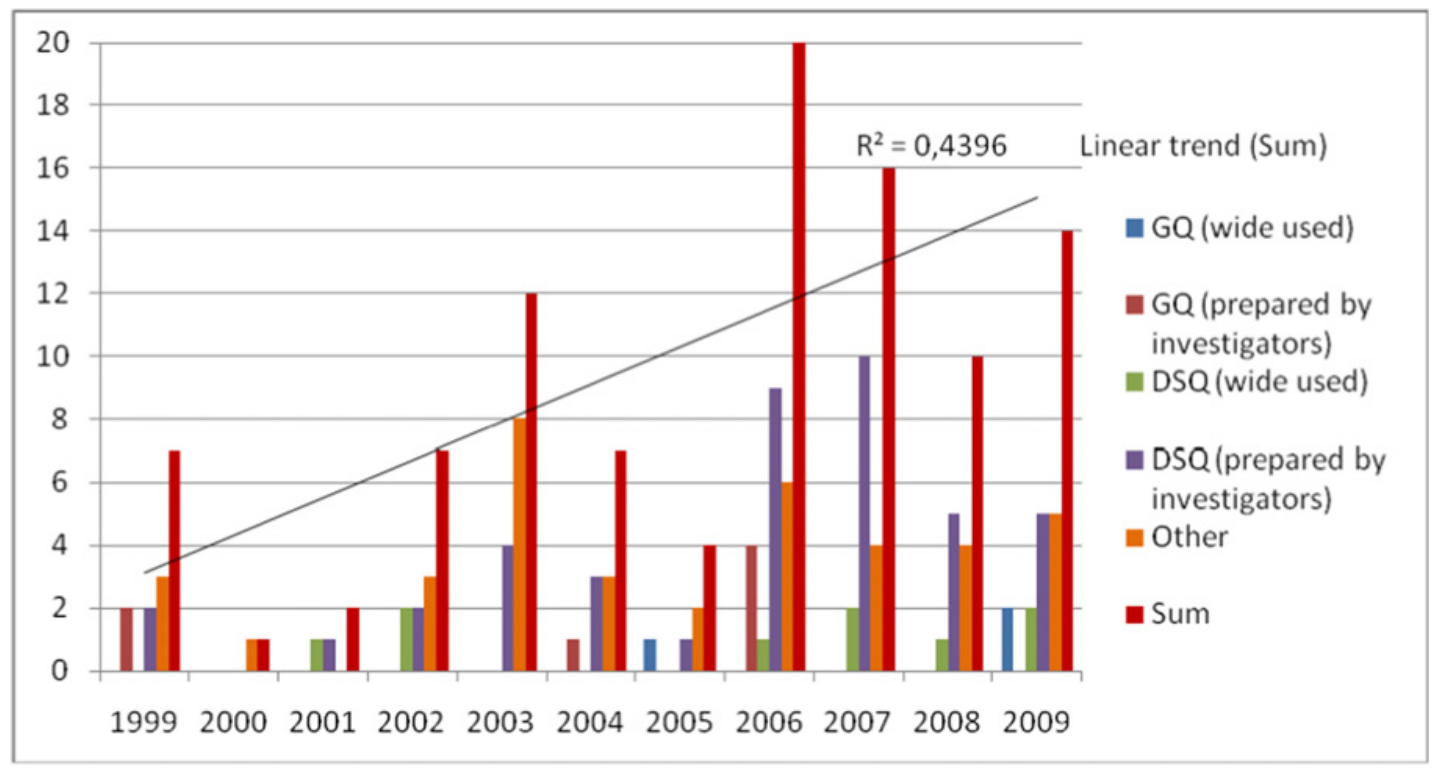

Figure 2. Trend in applying of patient - reported outcomes in health research in Latvia.

quality-adjusted survival, monetary outcome and relatively new group of the measures - the patientreported outcomes.

\section{The aim of this research}

Investigation of the patient-reported outcomes (PROs) as one of the treatment outcome measures for decision-making in health care system of Latvia. In author's opinion this issue becomes topical as due to the introduction of PROs the patient can change the status of a passive subject of treatment to the active participant of treatment.

According to the European Medicines Agency (EMA): "Any outcome based on a patient's perception of a disease and its treatment(s) scored by the patient himself is called a Patient-Reported Outcome (PRO). PROs are a large set of patient-assessed measures ranging from single item (e.g., pain VAS, overall treatment evaluation, and clinical global improvement) to multi-item tools. Multiitem tools can be mono-dimensional (e.g., measuring a single dimension such as physical functioning, fatigue, and sexual function) or multi-dimensional questionnaires measuring several of the following: 
Int. Conf. SOCIETY. HEALTH. WELFARE; Congr. of Rehabilitation Doctors of Latvia

symptoms, functional status, satisfaction, well-being, or health-related quality of life (HRQL). In general terms, PROs provide information on the patient's perspective of a disease and its treatment." (Reflection paper on the regulatory guidance for the use of health-related quality of life (HRQL) measures in the evaluation of medicinal products, 2005). The Food and Drug Administration (FDA) of the United States of America suggests the following definition: "Any report of the status of a patient's health condition that comes directly from the patient, without interpretation of the patient's response by a clinician or anyone else." (Guidance for Industry. Patient-Reported Outcome Measures: Use in Medical Product Development to Support Labelling Claims, 2009).

The disease and treatment process impact the patients' physical, mental and social functioning and the objective of treatment is to improve patients' quality of life. The classical clinical measures are often inadequate to describe and evaluate this effect, and a number of instruments to measure healthrelated quality of life (HRQL) have been developed. Instruments to measure PROs fall into three basic categories that are used in different circumstances and for different purposes (Kielhorn, Graf von der Schulenburg, 2000; Kobelt, 2002):

- general measures (EuroQol EQ-5D, Short Form 12 (SF-12), Short Form 36 (SF-36), Nottingham Health Profile (NHP), Sickness Impact Profile (SIP), Health Utilities Index (HUI), etc.);

- disease-specific measures (Arthritis Impact Measurement Scale (AIMS), Minnesota Living with Heart Disease Scale, Multiple Sclerosis Quality of Life Inventory (MSQLI), Beck Depression Inventory (BDI), etc.);

- preference-based measures (utility measures) (they yield a set of weights on which Quality Adjusted Life Years (QALYs) calculations can be based. Some generic instruments will yield an overall quality of life score as an index and can therefore be treated as utility measures suitable for generating QALYs. The EuroQol EQ-5D is often use in this way).

\section{Materials and methods}

The scientific literature review is used to achieve the aim of the research. Author investigates the scientific publications of the Riga Stradiņš University, as a leader of the university level medical education and research in Latvia, in the time score of 1999-2009. The publications are specified by type of the used PROs questionnaires. Their amount in total number of publications and trends are calculated (Table 1).

\section{Results}

Table 1. Results of the scientific publications review of the Riga Stradiņš Universityon Patient-Reported Outcomes in $1999-2009[3 ; 4 ; 5 ; 6 ; 7 ; 8 ; 9 ; 10 ; 11 ; 12 ; 13 ; 14]$.

\begin{tabular}{|c|c|c|c|c|c|c|c|}
\hline \multirow[t]{2}{*}{ Year } & \multicolumn{5}{|c|}{$\begin{array}{l}\text { Number of publications specified by type of the used } \\
\text { PROs questionnaire }\end{array}$} & \multirow{2}{*}{$\begin{array}{l}\text { Per cent of } \\
\text { the total } \\
\text { number of } \\
\text { publications }\end{array}$} & \multirow[t]{2}{*}{ Comments } \\
\hline & $\begin{array}{c}\text { GQ } \\
\text { (widely } \\
\text { used) }\end{array}$ & $\begin{array}{c}\text { GQ } \\
\text { prepared by } \\
\text { investigators) }\end{array}$ & $\begin{array}{c}\text { DSQ } \\
\text { (widely } \\
\text { used) }\end{array}$ & $\begin{array}{c}\text { DSQ } \\
\text { (prepared by } \\
\text { investigators) }\end{array}$ & other & & \\
\hline 1 & 2 & 3 & 4 & 5 & 6 & 7 & 8 \\
\hline \multirow{4}{*}{1999} & & & & & 3 & \multirow{4}{*}{$6,5 \%$} & Occupational health risks assessment \\
\hline & & 2 & & & & & Schoolchildren health assessment \\
\hline & & & & 1 & & & Treatment of post-radiation syndrome \\
\hline & & & & 1 & & & Diabetes control \\
\hline 2000 & & & & & 1 & $2 \%$ & Occupational health risks assessment \\
\hline \multirow{2}{*}{2001} & & & 1 & & & \multirow{2}{*}{$3,1 \%$} & Pain VAS \\
\hline & & & & 1 & & & Neurologic pain assessment \\
\hline
\end{tabular}




\section{SHS Web of Conferences}

Table 1. Continued.

\begin{tabular}{|c|c|c|c|c|c|c|c|}
\hline \multirow{3}{*}{2002} & & & 2 & & & \multirow{3}{*}{$8 \%$} & Pain VAS \\
\hline & & & & 2 & & & Gynaecology and contraception \\
\hline & & & & & 3 & & Social environment and dental health \\
\hline \multirow{8}{*}{2003} & & & & 2 & & \multirow{8}{*}{$12,2 \%$} & Post-surgery pain assessment \\
\hline & & & & 1 & & & Diabetes control \\
\hline & & & & 1 & & & Hypertension control \\
\hline & & & & & 1 & & Income level and medical care accessibility \\
\hline & & & & & 1 & & Sexual behaviour \\
\hline & & & & & 2 & & Health behaviour in school-age children \\
\hline & & & & & 3 & & Occupational health risks assessment \\
\hline & & & & & 1 & & Nutrition and dental health \\
\hline \multirow{7}{*}{2004} & & & & 1 & & \multirow{7}{*}{$8,2 \%$} & Gastroenterology \\
\hline & & & & 1 & 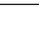 & & Diabetes control \\
\hline & & & & & 1 & & Medical services quality assessment \\
\hline & & & & & 1 & & Occupational health risks assessment \\
\hline & & 1 & & & & & Students' health assessment \\
\hline & & & & & 1 & & Employment of the mental patients' assessment \\
\hline & & & & 1 & & & Cystic fibrosis \\
\hline \multirow{3}{*}{2005} & & & & & 2 & \multirow{3}{*}{$11,7 \%$} & Occupational health risks assessment \\
\hline & 1 & & & & & & SF-36 \\
\hline & & & & 1 & & & Supplementary gene analysis \\
\hline \multirow{12}{*}{2006} & & & & 1 & & \multirow{12}{*}{$26 \%$} & $\begin{array}{l}\text { Psychiatric patients' questionnaire (filled } \\
\text { in by assistance of medical professionals) }\end{array}$ \\
\hline & & & & 1 & & & Neurologic pain assessment \\
\hline & & & 1 & & & & Pain VAS \\
\hline & & & & 5 & & & Family cancer history \\
\hline & & & & & 1 & & Health behaviour in school-age children \\
\hline & & 1 & & & & & $\begin{array}{l}\text { General mental and physical health } \\
\text { questionnaire of male population } \\
\text { above } 65 \text { years age }\end{array}$ \\
\hline & & & & & 1 & & $\begin{array}{l}\text { Assessment of young people attitude } \\
\text { and information about genetics }\end{array}$ \\
\hline & & 1 & & & & & Geriatric patients' quality of life questionnaire \\
\hline & & 1 & & & & & $\begin{array}{l}\text { Health assessment questionnaire of the } \\
\text { female population above } 35 \text { years age }\end{array}$ \\
\hline & & & & & 4 & & Occupational health risks assessment \\
\hline & & & & 2 & & & Diabetes control \\
\hline & & 1 & & & & & Students' health assessment \\
\hline \multirow{11}{*}{2007} & & & & & 2 & \multirow{11}{*}{$20,8 \%$} & Occupational health risks assessment \\
\hline & & & & 1 & & & $\begin{array}{l}\text { Palliative care of children } \\
\text { (questionnaire of parents) }\end{array}$ \\
\hline & & & & & 1 & & $\begin{array}{l}\text { Personality self-assessment by Friedman } \\
\text { and Rosenman questionnaire }\end{array}$ \\
\hline & & & 1 & & & & MADRS and HAM-A \\
\hline & & & & 2 & & & GR disease \\
\hline & & & 1 & & & & Woodcock-Johnson tests of cognitive ability \\
\hline & & & & 1 & & & $\begin{array}{l}\text { Surgically treated EA children } \\
\text { (questionnaire of parents) }\end{array}$ \\
\hline & & & & 4 & & & Family cancer history \\
\hline & & & & 1 & & & Hypertension control \\
\hline & & & & & 1 & & Questionnaire to reveal psychosocial stress \\
\hline & & & & 1 & & & Children with CCMN (questionnaire of parents) \\
\hline \multirow{7}{*}{2008} & & & & 3 & & \multirow{7}{*}{$14,9 \%$} & Family cancer history \\
\hline & & & & & 2 & & Occupational health risks assessment \\
\hline & & & & 1 & & & $\begin{array}{l}\text { Effectiveness of physiotherapy of } \\
\text { the Bronhiectatic disease }\end{array}$ \\
\hline & & & & 1 & & & Neurologic pain assessment \\
\hline & & & 1 & & & & Likert's VAS \\
\hline & & & & & 1 & & Pharmaceutical care quality assessment \\
\hline & & & & & 1 & & Medication habits of geriatric patients \\
\hline
\end{tabular}


Int. Conf. SOCIETY. HEALTH. WELFARE; Congr. of Rehabilitation Doctors of Latvia

Table 1. Continued.

\begin{tabular}{|c|c|c|c|c|c|c|c|}
\hline \multirow{12}{*}{2009} & & & 1 & & & \multirow{12}{*}{$18,9 \%$} & AQLQ-S \\
\hline & & & & 1 & & & Dental surgery \\
\hline & & & & & 1 & & e-Health Consumer Trends questionnaire \\
\hline & & & & & 2 & & Occupational health risks assessment \\
\hline & & & & 1 & & & Medication adverse reactions assessment \\
\hline & & & & 1 & & & Post-surgery pain assessment \\
\hline & & & & 2 & & & Addictions treatment \\
\hline & & & & & 1 & & Complex personality self-assessment questionnaire \\
\hline & & & 1 & & & & Pain VAS \\
\hline & 1 & & & & & & HEPRO \\
\hline & 1 & & & & & & Modified EuroQol \\
\hline & & & & & 1 & & Assessment of immunisation habits \\
\hline Sum: & 3 & 7 & 9 & 42 & 39 & Av: $12 \%$ & \\
\hline
\end{tabular}

Abbreviations:

PROs - patient-reported outcomes

$G Q$ - general questionnaire of health self-assessment

$D S Q-$ disease-specific questionnaire

VAS - Visual Analogue Scale

MADRS - Montgomery-Asberg Depression Rating Scale

GR - Gastroesophagel Reflux

EA - Esophageal Atresia

HAM-A - Hamilton Rating Scale of Anxiety

CCMN - Common Congenital Malformation in Newborns

AQLQ-S - Asthma Quality of Life Questionnaire

HEPRO - project "Health and Environment in the Baltic Sea Region".

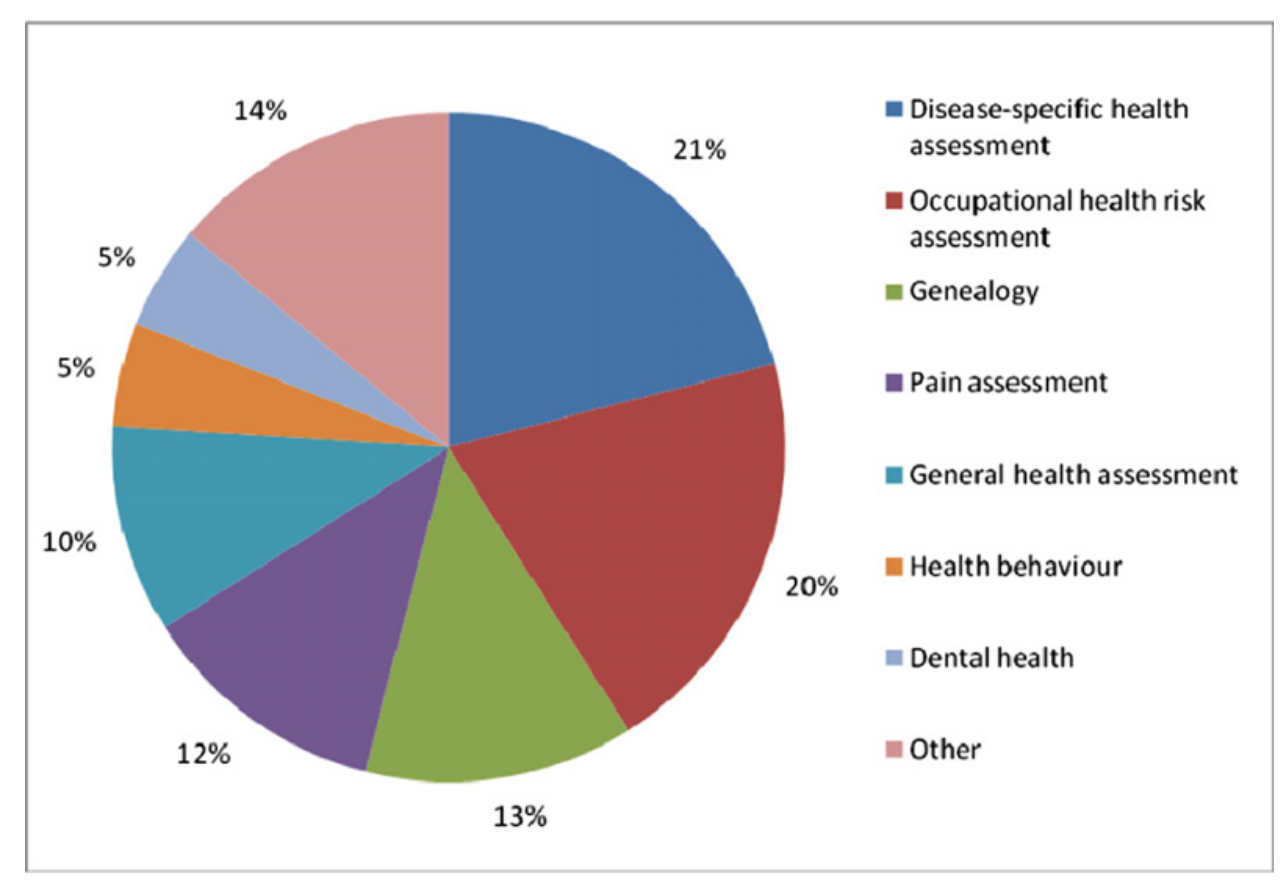

Figure 3. Structure of patient - reported outcomes in health research in Latvia.

\section{Discussion}

1. The results of the investigation show the positive trend in applying of the PROs in health research in Latvia (Figure 2).

But for discussion author proposes to evaluate the structure of these PROs (Figure 3). 


\section{SHS Web of Conferences}

The structure of the PROs is in compliance with the FDA definition mentioned in introductory part of the article:"...any report of the status of a patient's health condition that comes directly from the patient...", but at the same time it is in some contradiction with the EMA provided definition “...any outcome based on a patient's perception of a disease and its treatment( $($ ) scored by the patient himself is called a Patient-Reported Outcome $(P R \bar{O}) \ldots$ In general terms, PROs provide information on the patient's perspective of a disease and its treatment.". Looking on the structure of PROs in view of the EMA definition less than half of the reported outcomes is related to the concrete disease and its treatment. Large part of the reported outcomes is dedicated to health risks assessment, prevention activities, health behaviour, etc.

2. The indicator of the research with applying of PROs as part of the total number of publications in the time score of 1999-2009 (Table 1) show that the applying of PROs rose until 26\% in 2006 and decreased in the next years. It could be forecasted that without additional encouraging this indicator will not rise above $20 \%$ in future. In author's opinion the main reasons are the following:

- health professionals are not enough informed about advantages of the PROs;

- health professionals don't trust the validity and objectivity of the PROs;

- not all patients are ready to make their health self-assessment. In 2008 the author carried out the study where the modified EuroQol questionnaire was used for evaluating of the health-related quality of life (HRQL) of the pharmacies' visitors with later involving these data in investigation of the possibilities of using cost-utility analysis of the medication process in Latvia (Arāja, 2010). Although the used questionnaire is classified as one of the simplest general type HRQL questionnaires it was difficult to complete for the people who have not previously encountered such health self-assessment.

3. It must be considered that in accordance with the new legislative initiative of European Union on pharmacovigilance (Regulation (EU) No 1235/2010 and Directive 2010/84/EU) patients will be allowed to report adverse drug reactions directly to the competent authorities. Additionally, reporting of adverse reactions will be broadened to cover, for example, medication errors and overdose. The new legislation will become applicable in July 2012 [15; 16]. In author's opinion the patient-reported adverse reactions will be the new form of the PROs and question about the readiness of patients in Latvia to make objective assessment of the adverse drug reactions should be under consideration.

4. Taking into account the increasing role of the PROs the crucial point becomes the establishment of the effective and appropriate mechanism for educating of patients in relevant fields. Widely this process should cover the population from the school-age children to retirees, but in the shorter time the main responsibility on educating of patients could be competence of health professionals.

5. Concerning to encouraging the health professionals to use the PROs advantages the question about availability of the Latvian version of the widely used questionnaires is discussible. The questionnaires are available in the Internet and the respective website also provides translated versions in different languages. The largest part of questionnaires is not currently available in Latvian language and it could be one of the possible problems of their applying in Latvia, as the results of this research show very small amount of widely used questionnaires. The researchers choose to use self-prepared questionnaires, but their validity is discussible. For this reason the initiative of the group of researchers (Voicehovska et al., 2010) to study the evaluative and discriminative properties of the Asthma Quality of Life Questionnaire (AQLQ-S) Latvian language version is highly appreciated.

\section{References}

[1] Reflection paper on the regulatory guidance for the use of health-related quality of life (HRQL) measures in the evaluation of medicinal products (2005). CHMP: Committee for Medicinal Products for Human Use. 
Int. Conf. SOCIETY. HEALTH. WELFARE; Congr. of Rehabilitation Doctors of Latvia

[2] Guidance for Industry. Patient-Reported Outcome Measures: Use in Medical Product Development to Support Labelling Claims (2009). U.S. Food and Drug Administration: Federal Register.

[3] Zinātniskie raksti 2000. Pirmā daļa: 1999. gada medicīnas nozares pētnieciskā darba publikācijas. Madona: Latvijas Medicīnas akadēmija.

[4] Zinātniskie raksti 2000. Otrā daļa: 1999. gada medicīnas nozares pētnieciskā darba publikācijas. Madona: Latvijas Medicīnas akadēmija.

[5] Zinātniskie raksti 2001. 2000. gada medicīnas nozares pētnieciskā darba publikācijas. Madona: Latvijas Medicīnas akadēmija.

[6] Zinātniskie raksti 2002. 2001. gada medicīnas nozares pētnieciskā darba publikācijas. Madona: Latvijas Medicīnas akadēmija/R̄̄gas Stradiņa Universitāte.

[7] Zinātniskie raksti 2003. 2002. gada medic̄̄nas nozares pētnieciskā darba publikācijas. Madona: Rīgas Stradiņa Universitāte.

[8] Zinātniskie raksti 2004. 2003. gada medicīnas nozares pētnieciskā darba publikācijas. Rīga: Rīgas Stradiņa Universitāte.

[9] Zinātniskie raksti 2005. 2004. gada medicīnas nozares pētnieciskā darba publikācijas. Rīga: Rīgas Stradiņa Universitāte.

[10] Zinātniskie raksti 2006. 2005. gada medicīnas nozares pētnieciskā darba publikācijas. Rīga: Rīgas Stradiņa Universitāte.

[11] Zinātniskie raksti 2007. 2006. gada medicīnas nozares pētnieciskā darba publikācijas. Rīga: Rīgas Stradiņa Universitāte.

[12] Zinātniskie raksti 2008. 2007. gada medicīnas nozares pētnieciskā darba publikācijas. Rīga: Rīgas Stradiņa Universitāte.

[13] Zinātniskie raksti 2009. 2008. gada medicīnas nozares pētnieciskā darba publikācijas. Rīga: Rīgas Stradiņa Universitāte.

[14] Zinātniskie raksti 2010. 2009.gada medicīnas nozares pētnieciskā darba publikācijas. R̄̄̄ga: Rīgas Stradiņa Universitāte.

[15] Regulation (EU) No 1235/2010 of the European Parliament and of the Council, of 15 December 2010, amending, as regards pharmacovigilance of medicinal products for human use, Regulation (EC) No 726/2004 laying down Community procedures for the authorisation and supervision of medicinal products for human and veterinary use and establishing a European Medicines Agency, and Regulation (EC) No 1394/2007 on advanced therapy medicinal products. - OJEU: Official Journal of the European Union.

[16] Directive 2010/84/EU of the European Parliament and of the Council, of 15 December 2010, amending, as regards pharmacovigilance, Directive 2001/83/EC on the Community code related to medicinal products for human use. - OJEU: Official Journal of the European Union.

[17] Arāja, D. (2010) Medikamentozās ārstēšanas izmaksu-derīguma analīzes iespēju noteikšana Latvijā. Zinātniskie raksti 2010. 2009. gada medicīnas nozares pētnieciskā darba publikācijas. Rīga: Rīgas Stradiņa Universitāte, 535.-541. lpp.

[18] Voicehovska, J., Orļikovs, G., Voskresenska, N., Mauliòš, E., Farbtuha, T., Karpovs, J. (2010) Asthma Quality of Life Questionnaire latviešu valodas versija: izpēte, validēšana, dzīves kvalitātes novērtēšana slimniekiem ar bronhiālo astmu. Zinātniskie raksti 2010. 2009.gada medicīnas nozares pētnieciskā darba publikācijas. Rīga: Rīgas Stradiņa Universitāte, 8.-13. lpp.

[19] Drummond, M.F., O’Brien, B.J., Stoddart, G.L., Torrance, G.W. (2000) Methods for the Economic Evaluation of Health Care Programmes. Oxford: Oxford University Press, p. 296.

[20] Kielhorn, A., Graf von der Schulenburg, J.-M. (2000) The Health Economics Handbook. England: Adis International Limited, p. 158.

[21] Kobelt, G. (2002) Health Economics: An Introduction to Economic Evaluation. London: Office of Health Economics, p. 131. 